Химич Нінель Євгенівна кандидат педагогічних наук, доцент, завідувач лабораторії духовного розвитку особистості, Університет Григорія Сковороди в Переяславі, вул. Сухомлинського, 30, м. Переяслав, 08401,тел.: (045) 675-56-45, еmail: uhsp.edu@gmail.com, https://orcid.org/0000-0002-3953-3416

\title{
ВИХОВАННЯ ДУХОВНОГО ПОТЕНЦАЛУ СТУДЕНТСЬКОЇ МОЛОДІ НА ХРИСТИЯНСЬКИХ МОРАЛЬНИХ ЦІННОСТЯХ
}

Анотація. Серед першочергових для вирішення проблем сучасної освіти в Україні окреме місце належить поліпшенню й вдосконаленню процесу виховання в умовах розбудови національної системи освіти У нинішній складній суспільнополітичній ситуації 3 iї викликами, загрозами та водночас великими перспективами розвитку.

У статті обгрунтовується актуальність та необхідність виховання духовного потенціалу молодого покоління на християнських моральних цінностях. Звертається увага на те, що серед сучасних освітніх напрямків одним із найактуальніших $\epsilon$ духовно-моральне виховання як ключове, фундаментальне, яке відповідає сучасним вимогам та викликам, і закладає грунт для формування свідомості нинішнього та майбутніх поколінь.

Автором здійснено аналіз досліджень провідних вчених 3 проблеми цінностей, ціннісних орієнтацій особистості та впливу духовних цінностей на формування духовного потенціалу дітей і молоді. Аналізується стан освіти, моралі та освітньої політики в державі. Акцентується увага на тому, що вищим рівнем морального розвитку людини $є$ духовний, саме духовно-моральні цінності є стрижневими, основоположними в системі ціннісних орієнтацій особистості. Тому процес духовно-морального виховання дітей та молоді варто розглядати як цілісну систему, що поєднує у собі: засвоєння знань, необхідних для життєдіяльності, формування готовності до вдосконалення духовного потенціалу, набуття практичного досвіду дотримання духовно-моральних норм, виховання інтересу до саморозвитку й самовиховання.

На основі порівняльного аналізу світської та духовної моделі виховання показано переваги християнських духовно-моральних цінностей над світською мораллю (вони більш стійкі, універсальні, не підвладні різноманітним соціополітичним впливам; завжди мають морально-категоріальний імператив, що орієнтує на внутрішню роботу над собою, вдосконалення душі; $є$ джерелом базових загальнолюдських цінностей, їх фундаментом; розкривають поняття істинного гуманізму; містять єдине джерело як носія етичних норм - Абсолют).

Автором статті висвітлюється також напрацьований досвід із втілення ціннісних засад християнства в систему роботи закладу вищої освіти на прикладі 
викладання спецкурсу «Виховання особистості на засадах християнської моралі» для студентів спеціальності «Дошкільна освіта» університету Григорія Сковороди в Переяславі. Презентується позитивний досвід діяльності лабораторії духовного розвитку особистості в аспекті виховання духовного потенціалу студентської молоді в освітньому процесі закладу вищої освіти.

Ключові слова: цінності, духовні цінності, християнські духовно-моральні цінності, духовний потенціал, християнська мораль, духовно-моральне виховання.

Khymych Ninel Yevhenivna Candidate of Pedagogical Sciences, Associate Professor, Head of the Laboratory of Spiritual Development of Personality, Hryhoriy Skovoroda University in Pereyaslav, Sukhomlinskoho St., 30, Pereyaslav, 08401, tel.: (045) 675-56-45, e-mail: uhsp.edu @ gmail.com, https://orcid.org/0000-0002-3953-3416

\section{EDUCATION OF THE SPIRITUAL POTENTIAL OF STUDENT YOUTH ON CHRISTIAN MORAL VALUES}

Abstract. Among the priorities for solving the problems of modern education in Ukraine a special place belongs to the improvement and improvement of the process of education in the development of the national education system in the current difficult socio-political situation with its challenges, threats and great prospects.

The article substantiates the relevance and necessity of educating the spiritual potential of the younger generation on Christian moral values. Attention is drawn to the fact that among modern educational areas one of the most relevant is spiritual and moral education as a key, fundamental, which meets modern requirements and challenges, and lays the groundwork for the formation of consciousness of present and future generations.

The author analyzes the research of leading scientists on the problem of values, value orientations of the individual and the influence of spiritual values on the formation of the spiritual potential of children and youth. The state of education, morals and educational policy in the state is analyzed. Emphasis is placed on the fact that the highest level of moral development of man is spiritual, it is spiritual and moral values are the core, fundamental in the system of value orientations of the individual. Therefore, the process of spiritual and moral education of children and youth should be considered as a holistic system that combines: acquisition of knowledge necessary for life, formation of readiness to improve spiritual potential, gaining practical experience of spiritual and moral norms, education interest in self-development and self-education.

Based on a comparative analysis of the secular and spiritual model of education shows the advantages of Christian spiritual and moral values over secular morality (they are more stable, universal, not subject to various socio-political influences; always have a moral-categorical imperative, focusing on inner work on self is the source of basic universal values, their foundation, reveal the concept of true humanism, contain a single source as a carrier of ethical norms - the Absolute). 
The author of the article also highlights the experience gained in implementing the values of Christianity in the system of higher education on the example of teaching a special course "Education of the individual on the basis of Christian morality" for students majoring in "Preschool Education" at Hryhoriy Skovoroda University in Pereyaslav. The positive experience of the laboratory of spiritual development of personality in the aspect of education of spiritual potential of student's youth in the educational process of the institution of higher education is presented.

Keywords: values, spiritual values, Christian spiritual and moral values, spiritual potential, Christian morality, spiritual and moral education.

Постановка проблеми. В сучасному суспільстві, де панує ідеологія лібералізму та морального релятивізму, коли змітаються всі цінності, процвітає вседозволеність, знецінюються моральні норми, особливо актуальною є проблема виховання основ високої духовності у молодого покоління. Постала необхідність суттєво поновлювати виховний процес закладів освіти такими духовноморальними цінностями, які сприятимуть формуванню нової генерації, що житиме за законами Добра. На превеликий жаль, вітчизняна освіта, що переживає кризу всієї системи навчання й виховання, не в змозі оперативно реагувати на всі виклики. Сучасна психолого-педагогічна наука та практика, на думку І. Сіданіч, характеризується відсутністю сталих організаційних і змістовно-методичних важелів забезпечення духовно-морального виховання дітей і молоді. Нагальним $є$ вирішення низки суперечностей, зокрема: 1) між потребою переходу від гуманізації й гуманітаризації виховного процесу до створення духовно-морального середовища, спрямованого на самовдосконалення дітей i молоді, глибоке розуміння й чітке тлумачення духовно-моральних концептів, цільових настанов і педагогічних засобів їх упровадження; 2) між значенням категорії духовно-морального виховання в структурі особистісно орієнтованої педагогіки та недостатнім наповненням змісту освітнього процесу закладів освіти духовно-моральними цінностями; 3) між потребою суспільства в науковому осмисленні процесів становлення і розвитку ідеї духовно-морального виховання особистості та відсутністю вітчизняних комплексних досліджень цієї проблеми; 4) між запитами та потребами українського соціуму в якісній професійній підготовці педагогів і недостатньою готовністю їх до викладання дисциплін духовно-морального спрямування у вітчизняних закладах освіти [1]. Тому часто можна спостерігати, як різноманітні виховні заходи, що організовуються у стінах освітніх закладів, зокрема ЗВО, виявляються формальними й безрезультатними, бо не торкаються струн душі молодої людини, не збагачують ii внутрішній світ, отже й не сприяють формуваню духовно-морального потенціалу молоді.

Формування духовного світу студентів - завдання нелегке. Адже це люди, які мають вже певною мірою сформований світогляд, власні переконання, ідеали, які часто побудовані на стереотипах антикультури. Тому іноді доводиться мати справу з низькодуховним контингентом студентів, яким окремі виховні вузівські 
заходи не потрібні. Тут слід шукати інші шляхи впливу на особистість. Ті, що спонукатимуть замислитися, озирнутися довкола себе, переглянути свої погляди та поведінку. Ускладнюється цей процес тим, що «ми живемо в період уламків ціннісних систем», як зазначає А. Баумейстер [2]. Це посилює відповідальність педагогів перед суспільством, перед майбутнім за нинішню молодь, за якість ії подальшого життя.

Аналіз останніх досліджень і публікацій. Аналіз досліджуваної проблеми дозволив констатувати, що серед основних складових становлення особистості почесне місце займає багатогранний процес виховання, який формує цінності. Цінність - це те, що є найбільш важливим, дорогим, визначальним, що допомагає жити і розуміти сенс життя, що возвеличується понад усе, стоїть «над» і до чого потрібно прагнути. Цінність - це не бажання, як констатує А. Баумейстер, а те, що гідне бути бажанням [2]. За визначенням Н. Лісової, цінність - це «будь-яке матеріальне чи ідеальне явище, яке має значення для людини або суспільства i заради якого вона діє, живе» [3, С.88]. Живучи в суспільстві, людина створює специфічний аксіосвіт - світ цінностей (соціально схвалюваних уявлень про добро, шляхетність, справедливість, патріотизм, любов, дружбу і т.д.), які фактично визначають ii існування. Світ людського буття - це світ цінностей. А. Баумейстер наголошує, що цінності - це ті стандарти і зразки, які людина сама собі обирає. Яким вона бачить світ, яким хоче його зробити, яким вона хоче стати сама - це питання цінностей. На відміну від норм і правил, цінності розширюють радіус поведінки людини, підвищують рівень видимого зараз, сприяють подоланню себе, діагностують те, що людина може бути більше, ніж вона $є$ [2].

Цінності інтеріоризуются дітьми та молоддю від оточуючих дорослих. Тому багато що залежить від педагога, який в значній мірі сприяе формуванню аксіосвіту своїх підопічних, впливаючи на них. Розрізняючи область цінностей, псевдоцінностей i антицінностей, педагог визначає смисловий вектор внутрішнього світу, обумовлюючи внутрішню самоактивність і зовнішню активність особистості.

У освітньому процесі будь-якого закладу (від ЗДО до ЗВО) велике значення має духовна складова. Саме духовні цінності відіграють першорядну роль у формуванні духовного потенціалу дітей та молоді. А. Баумейстер вважає, що духовні цінності - це речі, які не існують як предмети, вони нематеріальні, це вікна в трансцендентне. Духовні цінності І. Бех кваліфікує як «високосмислові, безумовні за виникненням утворення, на основі яких особистість формує власне Я-духовне і реалізує його в своїй життєдіяльності» [4, С.4]. Слід зауважити, що мова йде про особистісний духовний потенціал, який напрацьовується i вдосконалюється на підставі трьох основних складових: Істини, Добра, Краси, де Істина - свідомість, зерно духовності; Краса - протистояння потворному, емоційно-ціннісна форма вираження своїх переживань, свого ставлення до світу; Добро - вісь духовності, іiі моральна опора. Тому духовно-моральні цінності $\epsilon$ стрижневими, основоположними в системі ціннісних орієнтацій особистості.

Аналіз співвідношення моральності і духовності дозволила М. Савчину 
констатувати той факт, що «гола» моральність, яка не спирається на духовність, підпорядковує людину етичним імперативам. Але «крихкою та малоефективною є будь-яка автономна та іманентна етична система, що не містить ніякої животворної сили - духу» [5, С. 80]. Погоджуючись 3 точкою зору В. Братусь, вчений вважає найвищим рівнем морального розвитку - духовний, коли людина усвідомлює себе й інших людей не кінцевою смертною істотою, а творінням i образом Божим [Там само, С. 80-81].

Основою, фундаментом духовно-моральних цінностей $\epsilon$ християнські чесноти. Вони збереглися ще в радянську епоху при декларативному атеїзм, коли цінності пропагувалися, а джерело не називалося. «Моральний кодекс будівника комунізму» проголошував не тільки принципи комуністичної моралі, а й загальнолюдські норми життя, тобто християнські: взаємоповага між людьми, дружба, товариство, братство, моральна чистота, чесність, правдивість, скромність, взаємоповага в сім'ї, турбота про дітей і старших та інші. Таким чином, в епоху радянської влади збереглися моральні коди, що має велике значення для відродження духовно-моральних цінностей на новому витку еволюції, бо цінності виникають і прогресують в результаті природної еволюції.

Дослідження вчених останніх років (I. Бех, А. Богуш, С. Головін, В. Жуковський, О. Рогова, І. Сіданіч та ін.) свідчать про те, що християнські духовно-моральні цінності конче потрібні в сучасній освіті. В цьому також безсумнівно переконана значна частина прогресивної громадськості. Адже:

1. Освіта сьогодні продовжує формувати у підростаючого покоління односторонній атеїстичний світогляд, акцентується увага на іï світському характері. Однак світський характер освіти не означає атеїстичний. Тому всі учасники освітнього процесу повинні мати можливість свободи вибору в отриманні інформації. Отже цілком можливим є поєднання християнської та світської етики в площині гуманітарної методології.

2. Сьогодні мораль - стрижень духовності - перебуває в глибокій кризі, що негативно впливає на всі сфери нашого життя. Без освітнього закладу, як громадської освітньої інституції, і педагога, як носія цінностей, ні сім'я, ні церква, ні громада, маючи за переконанням В. Жуковського, серйозні проблеми у своєму середовищі, не спроможні виконати завдання духовно-морального виховання дітей і молоді [1].

3. В освітній політиці держави на сьогоднішній день мало уваги приділяється виховній функції освіти. Без досконалої виховної системи ми втрачаємо головний продукт нашої роботи - дітей та молодь. А досконалою виховна система є тоді, коли інтелектуальний і духовний розвиток гармонійний. Тобто необхідна обов'язкова наявність духовно-моральної складової. Це ще один доказ необхідності впровадження християнських цінностей в освітній процес закладів освіти на всіх рівнях.

Мета статті: розкрити необхідність виховання духовного потенціалу студентської молоді на християнських моральних цінностях, познайомити зі спецкурсом, спрямованим на професійне становлення та розширення духовних 
горизонтів майбутніх педагогів спеціальності «Дошкільна освіта», презентувати досвід діяльності лабораторії духовного розвитку особистості у даному напрямку.

Виклад основного матеріалу. Визнання християнських духовно-моральних цінностей основоположними в системі ціннісних орієнтацій особистості спонукало до здійснення порівняльного аналізу християнської та світської моралі. Аналіз показав, що християнські духовно-моральні цінності мають переваги над світською мораллю:

1) вони більш стійкі, універсальні, не піддаються різноманітним соціальнополітичним впливам, в той час, як світська мораль носить мінливий характер (наприклад, толерантне ставлення до гомосексуалізму та цивільних шлюбів);

2) завжди мають морально-категоріальний імператив, що орієнтує на внутрішню роботу, вдосконалення душі (всіх трьох іï складових: розум, волю, почуття);

3) християнські цінності - джерело базових загальнолюдських цінностей, їх фундамент;

4) розкривають поняття істинного гуманізму, де визнається гідність людини як образу і подоби Божої, вищого Його творіння на землі;

5) у християнстві існує єдине джерело, носій етичних норм - Господь. Він основний законодавець морального закону.

Отож християнська мораль абсолютна, не потребує доведення, як світська, iï норми цілісні й вимірюються єдиними вимогами, які йдуть від Творця по відношенню до свого творіння. Сприяють ці норми здобуттю особистістю подоби Божої, їх неможливо замінити.

Духовно-моральне виховання на християнських цінностях не суперечить світському тому, що $є$ складовою частиною національного виховання і яскравим представником духовної культури нації. Християнські цінності сприяють національній ідентифікації, вихованню національного характеру, формуванню самобутньої духовної культури особистості, є життєвими орієнтирами, що формують ідеали і стають нормами діяльності, допомагаючи кожному стати людиною. У закладах освіти вони не $є$ віровченням певної конфесії, засобом євангелізації особистості, натомість дають розуміння місця і призначення свого життя, впливають на мотивацію поведінки дітей i молоді, передбачають виховання поваги до свобод і переконань інших людей, здатності до співжиття в полікультурному та поліконфесійному суспільстві.

Сьогодні ми знову повертаємося до християнського виховного ідеалу, обгрунтованого Г. Ващенком як «образу ідеальної людини, на який має орієнтуватися педагог, виховуючи молоде покоління» [ 6, С. 41], центральним пунктом у якому $\epsilon$ виховання дюбові до людини та чистоти серця, відчуття духовного братерства. Християнська мораль - фундамент загальнолюдських та національних життєвих цінностей - спрямована не на зовнішню сторону особистості, а на іiі внутрішній світ. Розбудова себе внутрішнього, плекання внутрішньої людини - ось у чому суть духовного вдосконалення. А ідеалом 
досконалості $є$ ціннісні засади християнства, закріплені в універсальних вічних вартостях життя: правда, добро, краса, любов, свобода, відповідальність, щирість, віра, надія, гідність, справедливість, чесність, скромність, великодушність, милосердя та ін. К.Ушинський зауважує: «Є лише один ідеал досконалості.., це ідеал, представлений нам християнством. ...І вихованню залишається лише, перш за все і в основу всього, вкорінити вічні істини християнства. Воно дає життя i вказує найвищу мету будь-якому вихованню, воно ж і повинно служити для виховання... джерелом світла й істини. Це незгасимий світоч, що йде вічно, як вогняний стовп в пустелі, попереду людини й народів; за ним повинен прямувати розвиток народності й істинне виховання, що йде разом з народністю» [7, С. 52].

Виховання духовно-морального потенціалу сучасного студентства на засадах християнських моральних цінностей - досить складний процес. Адже рівень свідомості студентів різний. Дається взнаки також і наявність чи відсутність життєвого досвіду. Про це свідчать результати роботи зі студентами університету Григорія Сковороди в Пекреяславі, де в навчальний план спеціальності «Дошкільна освіта» введено спецкурс «Виховання особистості на засадах християнської моралі». Перед викладанням курсу завжди проводиться попереднє анкетування, яке показує ставлення студентів до християнської проблематики. Зазвичай близько $25 \%$ студентів заочної форми навчання та $45 \%$ студентів стаціонару взагалі не розуміють цю проблему, але бажають опановувати основи християнської моралі. Тому матеріал, який пропонується слухачам, розрахований на різний рівень сприймання.

В основі роботи зі студентами лежить принцип невтручання у свободу особистості: ніхто не може змусити чи заборонити пізнавати християнські цінності, кожен має право вивчати або не вивчати основи християнської моралі, але жити по-божому повинен кожен. При цьому головним є не євангелізація особистості (це функція Церкви), а духовно-моральне становлення молоді через цінності християнської культури.

Досвід викладання даного курсу свідчить про доречність використання такого матеріалу у освітньому процесі ЗВО. Адже він надихає на роздуми й самостійний пошук відповідей на безліч нових запитань, облагороджує людину.

До уваги педагогів пропонується фрагмент програми спецкурсу «Виховання особистості на засадах християнської моралі».

Мета курсу - озброїти студентів знаннями загальнолюдських засадових життєвих цінностей; сприяти усвідомленню важливості залучення нинішнього молодого покоління до християнської духовної традиції задля формування кращих людських рис, плекання високоморальної, духовно багатої української нації.

\section{Завдання курсу:}

- ознайомити студентів з християнськими духовно-моральними цінностями та зразками християнської культури;

- сприяти оволодінню механізмами виховання особистості на християнських моральних цінностях в умовах сім'ї та сучасних освітніх установ; 
- поглиблювати вміння творчого використання специфічних засобів, методів та форм педагогічної взаємодії 3 метою якісного формування духовноморального потенціалу зростаючої особистості;

- виховувати почуття любові до вищих цінностей та основ буття, моральні чесноти, прагнення до прояву доброчесної поведінки;

- поглиблювати інтерес до християнських моральних цінностей та бажання впроваджувати їх у практику професійної діяльності й особисте життя.

МОДУЛЬ І. Виховання молоді на засадах християнської моралі - основа духовного становлення нації.

TEMA 1. Історичні та сучасні аспекти духовно-морального виховання підростаючого покоління на християнських моральних цінностях

Актуальність культурно-виховного впливу християнства на підростаюче покоління в складному процесі духовного відродження України. Проблема виховання особистості у християнській педагогіці. Ціннісні засади християнства у поглядах видатних класиків педагогічної думки на духовно-моральне виховання підростаючого покоління.

Впровадження основних засад християнства в освітній процес закладів освіти України в сучасних умовах. Вимоги до особи вчителя, вихователя викладача основ християнської моралі.

\section{МОДУЛЬ ІІ. Одвічні питання у педагогіці. Біблія про сім'ю і родинне виховання.}

\section{TEMA 1. Основні закони християнського життя}

Десять Заповідей Божих (Декалог) - моральна основа життя людини, хартія гідності особистості. Дві головні Заповіді Любові - новозавітній Закон Божественної Любові. Заповіді Блаженств - ідеал морального життя людини. Золоте правило християнської етики: «У всьому, як хочете, щоб з вами чинили люди, так само чиніть їм і ви». Універсальний Моральний Закон людства: твори Добро - уникай зла.

\section{TEMA 2. Сім'я та шлюб у християнській традиції}

Значення родинного виховання в історичному й релігійному досвіді людства.

Суть християнського подружжя. Дошлюбна чистота. Сім'я - центр виховання у Біблії. Роль та обов'язки чоловіка і жінки в сім'ї. Біблія про виховання дітей. Мета і методи виховання.

TEMA 3. Специфіка духовного виховання особистості на християнських моральних цінностях.

Становлення майбутньої особистості у пренатальний період. Особливості поведінки батьків. Необхідність морального вдосконалення наставника малих дітей. Метод «внутрішнього творення». Загальні та спеціальні методи роботи 3 дітьми дошкільного віку. Форми і засоби духовно-моральної взаємодії дорослих 3 дітьми у християнській педагогіці та психології. 
Після вивчення курсу студенти, як правило, діляться своїми роздумами щодо прослуханого у залікових творах-есе, де розмірковують над болючими для них проблемами: «Добро і зло: протидія та співіснування», «Моральні основи сім’ї та християнська традиція», «Прощення в житті людини», «Творити Добро безкорисливо», «Вічні вартості життя» тощо. Подібні студентські роздуми підтверджують думку про те, що людина духовна в тій мірі, в якій вона задумується над цими питаннями й прагне дістати на них відповідь. I християнська мораль виступає тією основою, яка допомагає сформувати духовний світ особистості, отой внутрішній стержень, що сприяє сходженню по духовній вертикалі до вищої досконалості. Адже це є найважливішим завданням виховання.

Робота 3 виховання духовного потенціалу студентів на християнських моральних цінностях не обмежується лише рамками спецкурсу. Її розширенню й поглибленню сприяє діяльність лабораторії духовного розвитку особистості, яка покликана допомогти студентській молоді підготуватися до педагогічної праці в нових умовах життя, надати психологічну допомогу, познайомити зі світовими духовно-культурними цінностями, розкрити багатство досягнень людського духу. При лабораторії працює ініціативна група студентів, яка досліджує шляхи становлення людської духовності та особливості іï формування в сучасних умовах. Одним з важливих напрямків діяльності студентів є дослідження впливу християнських моральних цінностей на духовно-моральну сферу особистості.

Лабораторією духовного розвитку особистості організовуються різноманітні заходи: проведення конференцій, семінарів, диспутів, тренінгів, круглих столів, зустрічей з цікавими людьми, благодійних акцій, екскурсій до духовних святинь українського народу тощо. Також налагоджуються творчі зв'язки з педагогічними колективами різних типів закладів освіти міста, району, держави. Головні зусилля у вихованні духовного потенціалу студентської молоді спрямовані на досягнення такої необхідної для повноцінної реалізації гармонії між власним життям та навколишнім світом.

Висновки. Сучасний заклад освіти має бути «осередком духовності i моральності», де здійснюється поступове сходження людини до духовних висот [7, С. 4-5]. Тому потрібен і педагог, який іде новими шляхами, несе новизну, сіє в дитячі душі ті невидимі зерна, які дадуть плідний урожай. I наш святий обов'язок: допомогти такому педагогу здобути свій шлях сходження, який сприяє формуванню міцної духовної опори і майбутній реалізації на засадах Істини, Добра, Краси. Це шлях, на якому тісно переплітаються наукова думка й духовний досвід людства, справжнім уособленням якого $є$ вічні і священні християнські духовно-моральні цінності.

\section{Лimepamypa:}

1. Кривенко О. Духовність і мораль - стрижень освіти у школах: відбувся онлайнсемінар. Світогляд. 2021. 25. 02. https://cuttIy/GIOU2zh

2. Баумейстер А.О. Ценности и решения (Ч.2/6). 2019. https://youtu.be/K832IgYWrmM 
3. Лісова Н.І. Уроки довіри в сучасній школі (Словник-довідник). Черкаси: видавець Чабаненко Ю.А. 2019. 120 с.

4. Бех І.Д. Вихованець на шляху до духовних цінностей// Вічне слово. 2020. № 1-2. С. 4 - 5.

5. Савчин М.В. Здоров'я людини: духовний, особистісний і тілесний виміри (Монографія). Дрогобич: ПП «ПОСВІТ». 2019. 232 с.

6. Ващенко Г. Виховний ідеал. Полтава: Полтавський вісник. 1994. 191 с.

7. Амонашвили Ш.А. Истина школы. Киев: СПД А.М.Богданова. 2005. 72 с.

\section{References:}

1. Kryvenko O. (2021). Dukhovnist' i moral' - stryzhen' osvity u shkolakh: vidbuvsya onlaynseminar. [Spirituality and morality - the core of education in schools: an online seminar]. SvitohlyadOutlook. 2021. 25. 02. https://cuttIy/GIOU2zh [in Ukrainian].

2. Baumeister A.O. (2019). Tsennosti i resheniya. [Values and Decisions]. (Part 2/6) https://youtu.be/K832IgYWrmM [in Russian].

3. Lisova N.I. (2019). Uroky doviry v suchasniy shkoli (Slovnyk-dovidnyk).[Doviri lessons in modern schools (Dictionary-dovidnik)]. Cherkasy: publisher Chabanenko Yu.A. [in Ukrainian].

4. Bekh I.D. (2020). Vykhovanets' na shlyakhu do dukhovnykh tsinnostey.[ A pupil on the way to spiritual values]. Vichne slovo - Eternal word. 1-2. Pp. 4 - 5. [in Ukrainian].

5. Savchin M.V. (2019). Zdorov"ya lyudyny: dukhovnyy, osobystisnyy i tilesnyy vymiry (Monohrafiya). [Human health: spiritual, personal and physical dimensions (Monograph)]. Drohobych: PE "POSVIT". [in Ukrainian].

6. Vashchenko G. (1994). Vykhovnyy ideal. [ Educational ideal]. Poltava: Poltava Herald. [in Ukrainian].

7. Amonashvili Sh.A. (2005). Istina shkoly. [The truth of the school]. Kiev: SPD A.M. Bogdanov. [in Russian]. 